\title{
Inhibition of matrix metalloproteinase expression by menatetrenone, a vitamin $\mathrm{K} 2$ analogue
}

\author{
YASUSHI IDE ${ }^{1}$, HAO ZHANG $^{1,2}$, HIROSHI HAMAJIMA ${ }^{1}$, YASUNORI KAWAGUCHI ${ }^{1}$, YUICHIRO EGUCHI ${ }^{1}$, \\ TOSHIHIKO MIZUTA $^{1}$, KYOSUKE YAMAMOTO ${ }^{3}$, KAZUMA FUJIMOTO $^{1}$ and IWATA OZAKI $^{1,4}$ \\ ${ }^{1}$ Department of Internal Medicine, Saga Medical School, Saga University, 5-1-1 Nabeshima, Saga 849-8501, Japan; \\ ${ }^{2}$ Department of Surgery, The First Affiliated Hospital, China Medical University, Shenyang 110001, P.R. China; \\ ${ }^{3}$ Takagi Hospital, 141-11 Sakemi, Ohkawa City, Fukuoka 831-0016; ${ }^{4}$ Health Administration Center, \\ Saga Medical School, Saga University, 5-1-1 Nabeshima, Saga 849-8501, Japan
}

Received March 16, 2009; Accepted May 11, 2009

DOI: 10.3892/or_00000478

\begin{abstract}
Vitamin K2 (VK2) has been shown to have a potent anti-tumor effect against several cancer types including hepatocellular carcinoma (HCC), but the mechanisms remain to be elucidated. Matrix metalloproteinase (MMP) plays an important role in the invasion and metastasis of cancer cells, but it is not known whether VK2 regulates the expression of MMPs. Human HCC cell lines were treated with VK2 combined with 12-O-tetradecanoyl phorbol-13 acetate (TPA) and the expression of MMPs was examined by reporter gene assay, RT-PCR and Western blotting. VK2 inhibited the basal and TPA-induced expression of MMP-1, -3 and -7 at the transcriptional, mRNA and protein levels in a dosedependent manner. VK2 also inhibited the TPA-induced activation of NF- $\mathrm{kB}$ and AP-1 activity. The inhibitors against $\mathrm{NF}-\kappa \mathrm{B}$ and mitogen-activated protein kinases (MAP kinase) including ERK and JNK pathways suppressed TPA-induced luciferase activity of MMP-1, -3 and -7 promoters. These data suggest that VK2 inhibits MMP expression by suppressing NF- $\mathrm{kB}$ and MAP kinase activity and might be potentially useful in the treatment of HCC.
\end{abstract}

\section{Introduction}

Hepatocellular carcinoma (HCC) is the fifth most common cancer in the world and its incidence is reported to be increasing worldwide. HCC is highly aggressive and its prognosis is still not satisfactory. Recurrence and intrahepatic metastasis are considered to be the main causes of the poor prognosis of HCC $(1,2)$. Therapeutic reagents capable of

Correspondence to: Dr Iwata Ozaki, Department of Internal Medicine, Health Administration Center, Saga Medical School, Saga University, 5-1-1 Nabeshima, Saga 849-8501, Japan

E-mail: ozaki@cc.saga-u.ac.jp

Key words: hepatocellular carcinoma, vitamin K2, matrix metalloproteinase preventing the metastatic cascade, especially at the level of cellular invasion, may therefore contribute to an improved disease course of HCC.

Matrix metalloproteinases (MMPs), a large group of secreted proteinases, are known to play an important role in a variety of the physiological and pathological processes by degrading extracellular matrix proteins. The MMPs are reported to be overexpressed in many types of human malignant tumors including HCC and have been shown to participate in tumor invasion and the metastatic processes (3). In HCC, the altered expression of several MMPs including MMP-1, MMP-2, MMP-3, MMP-7, MMP-9 and MMP-14 (MT1-MMP) has been reported and this has also been suggested to contribute to their malignant potential (4-10). The identification of an agent capable of inhibiting the expression of MMPs may therefore potentially lead to the development of an anti-metastatic tumor drug.

Vitamin $\mathrm{K}$ is fat soluble vitamin that regulates clotting factors produced in the liver and matrix proteins present in the bone $(11,12)$. Vitamin $\mathrm{K}$ was originally identified as a coenzyme for a vitamin $\mathrm{K}$-dependent carboxylase that catalyzes the carboxylation of glutamic acid residues to produce $\gamma$ carboxy-glutamic acid. Previously, several vitamin K analogues have been reported to possess anti-tumor activity against such hematological malignancies and solid tumors as hepatocellular carcinoma (13-15). The administration of menatetrenone, a vitamin K2 (VK2) analogue, suppresses the recurrence of $\mathrm{HCC}$ after curative ablation therapy (16), or the development of HCC from cirrhotic livers (17) in the clinical setting. Vitamin K2 also suppresses the development and proliferation of HCC in vivo animal models (18-20). Otsuka et al showed that VK2 reduces the invasion of HCC cells as well as the proliferation of $\mathrm{HCC}$ cells in a protein kinase A (PKA)-dependent manner. Although the mechanisms involved in the growth suppression of HCC have been investigated and attributed to changes of cell cycle-related gene expression $(18,20)$, the mechanisms by which VK2 inhibits the invasion of HCC are still not fully understood.

Since MMPs are known to play an important role in cellular invasion and metastasis during the disease course of $\mathrm{HCC}$, the effects of VK2 on the expression of multiple MMPs 
were investigated. These results demonstrate the inhibitory effects of VK2 on the expression of multiple MMPs, via the protein kinase $\mathrm{C}(\mathrm{PKC})$-related pathway.

\section{Materials and methods}

Cell lines and reagents. The human $\mathrm{HCC}$ cell lines HepG2, Huh7, Hep3B and HLE were obtained from the Japanese Cancer Research Resources Bank (Osaka, Japan). The cells were cultured and maintained in Dulbecco's modified Eagle's medium (DMEM) (Life Technologies, Rockville, MD) at $37^{\circ} \mathrm{C}, 5 \% \mathrm{CO}_{2}$ containing $10 \%$ fetal bovine serum (FBS) (Life Technologies), $100 \mu \mathrm{g} / \mathrm{ml}$ of streptomycin and $100 \mathrm{U} / \mathrm{ml}$ of penicillin. Menatetrenone, a vitamin K2 analogue, was provided by the Eisai Co. (Tokyo, Japan). 12-O-tetradecanoylphorbor-13-acetate (TPA), parthenolide, and SB203580 were purchased from Sigma (St. Louis, MO, USA). PD98059 was purchased from Promega (Madison, WI); SP600125 was obtained from Calbiochem (San Diego, CA).

RNA isolation and semi-quantitative RT-PCR. The total RNA was extracted from the cultured HCC cells using Isogen (Nippon Gene, Tokyo, Japan) according to the manufacturer's instructions. The concentration of RNA was determined by spectrophotometry and the integrity of the samples was confirmed by visualizing $28 \mathrm{~S}$ and $18 \mathrm{~S}$ ribosomal RNA bands under ultraviolet light after gel electrophoresis. Semiquantitative RT-PCR was performed, as described previously $(9,10)$. Briefly, $1 \mu \mathrm{g}$ of total RNA was reverse transcribed with reverse transcriptase (Takara, Kyoto, Japan) using random primers. Subsequently, each RT reaction mixture was subjected to PCR amplification using Taq Gold polymerase (PerkinElmer, Branchburg, NJ) with cycle numbers varying from 15 to 40 . Each cycle consisted of heat denaturation $\left(94^{\circ} \mathrm{C}\right.$ for $1 \mathrm{~min})$, annealing $\left(55^{\circ} \mathrm{C}\right.$ for $\left.1 \mathrm{~min}\right)$ and extension $\left(72^{\circ} \mathrm{C}\right.$ for $2 \mathrm{~min})$. The PCR products were size-fractionated on $2 \%$ agarose gels and then visualized under ultraviolet light. The sequences of oligonucleotide primers used for RT-PCR to determine MMP-1, -2, -3, -7, -9 and GAPDH have been previously described (10).

Plasmids, transfection and luciferase assay. Human MMP-1, -3 and -7 promoter/reporter gene plasmids have been described previously $(9,10)$. The effects of vitamin K2 on MMP-1, -3 and -7 promoter activity, AP-1 and NF-кB transcriptional activity were detected by a luciferase assay using the method described by the supplier (Dual-Luciferase Reporter Assay System; Promega, Madison, WI). Luciferase expression plasmid pRL-SV40 (Promega) was co-transfected to normalize for transfection efficiency. The HCC cells were seeded onto 6 -well plates at $1 \times 10^{5}$ cells/well without antibiotics and incubated until $80 \%$ confluent at $37^{\circ} \mathrm{C}$. Next, the cells were washed twice with OPTI-MEM I Reduced Medium (Life Technologies), followed by the addition of $2 \mathrm{ml}$ of OPTI-MEM I Reduced Medium containing $1 \mu \mathrm{g}$ of target gene reporter plasmid, $0.5 \mu \mathrm{g}$ of pRL-SV40 luciferase plasmid and $15 \mu \mathrm{l}$ of lipofectamine 2000 reagent (Life Technologies). After $6 \mathrm{~h}$ of incubation, the medium was changed and the transfected cells were treated with the indicated doses of vitamin K2. After $24 \mathrm{~h}$ of treatment, the cells were washed twice with PBS and carefully scraped into $1 \mathrm{x}$ passive lysis buffer (Promega). The cell extracts were immediately assayed for luciferase activity using a Berthold Luminometer (MLR-100 Micro Lumino Reader; Corona Electric, Ibaragi, Japan).

Western blotting. The protein expression of MMP-1, -3 and -7 was investigated by Western blotting. Cells $\left(2 \times 10^{6}\right)$ cultured under various conditions were collected and lysed with extraction buffer containing $50 \mathrm{mM}$ Tris ( $\mathrm{pH} 7.5), 150 \mathrm{mM}$ $\mathrm{NaCl}, 0.1 \%$ SDS, 5 mM EDTA (pH 8.0), 1 mM PMSF, $10 \mu \mathrm{g} /$ $\mathrm{ml}$ trypsin inhibitor and $50 \mathrm{mM}$ iodoacetamide. After $30 \mathrm{~min}$ at $4^{\circ} \mathrm{C}$, the cell debris was eliminated by centrifugation at $15,000 \mathrm{rpm}$ for $20 \mathrm{~min}$ and the supernatant was collected. After measuring the protein concentration using a protein assay kit (Bio-Rad, Hercules, CA), $40 \mu \mathrm{g}$ of protein was mixed with SDS sample buffer, separated by SDS-PAGE, transferred to a polyvinylidene difluoride membrane (Bio-Rad) and blocked with $0.1 \%$ Tween and $5 \%$ skim milk overnight. The membranes were incubated with MMP-1 (Abcam Inc., Cambridge, MA), -3 (Santa Cruz Biotechnology, Santa Cruz, CA), and -7 (Daiichi Fine Chemical Co., Toyama, Japan) in PBS with $1 \%$ BSA for $1 \mathrm{~h}$. Anti-human $\beta$-actin antibodies (Biomedical Technologies, Stoughton, MA) were used as a control. The membranes were washed three times with $0.1 \%$ Tween-20 in PBS and stained with horseradish peroxidase-conjugated secondary antibodies. All immunoblots were detected by the enhanced chemiluminescence system (Amersham, Buckinghamshire, UK) according to the manufacturer's instructions.

Gelatin zymography. Gelatin zymography was carried out, as described previously (21). The cells were seeded onto plates in DMEM with $10 \%$ FBS. The cells were then washed and maintained in serum-free media for $24 \mathrm{~h}$ prior to the designated treatments with VK2. The conditioned media were collected after $24 \mathrm{~h}$, mixed with non-reducing sample buffer [62.5 mM Tris- $\mathrm{HCl}, \mathrm{pH} 6.8,2 \% \mathrm{SDS}, 25 \%$ (w/v) glycerol, $0.01 \%$ bromophenol blue] and subjected to electrophoresis on a $10 \%$ SDS-PAGE gel containing $0.1 \%(\mathrm{w} / \mathrm{v})$ gelatin. The resulting gels were washed in $10 \mathrm{mM}$ Tris $(\mathrm{pH} 8.0)$ containing $2.5 \%$ $(\mathrm{v} / \mathrm{v})$ Triton $\mathrm{X}$ and then incubated for $16 \mathrm{~h}$ in developing buffer (50 mM Tris- $\mathrm{HCl}, \mathrm{pH} 7.5,0.2 \mathrm{M} \mathrm{NaCl}, 10 \mathrm{mM} \mathrm{CaCl}_{2}$ and $1 \mu \mathrm{M} \mathrm{ZnCl}_{2}$ ) at $37^{\circ} \mathrm{C}$. The gels were subsequently stained using $0.5 \%$ Coomassie blue R-250 in 5\% (v/v) methanol and $10 \%(\mathrm{v} / \mathrm{v})$ acetic acid for $1 \mathrm{~h}$ and destained in $10 \%(\mathrm{v} / \mathrm{v})$ methanol, $5 \%(\mathrm{v} / \mathrm{v})$ acetic acid until the bands were seen.

Statistical analysis. Differences were determined using Student's t-test and a value of $\mathrm{P}<0.05$ was considered to be significant. All experiments were performed either in triplicate or more. The data are shown as the mean \pm standard deviation (SD).

\section{Results}

VK2 inhibits expression of several MMPs in HCC cells. The expression of MMP-1, -2, -3, -7 and -9 mRNA in human HCC cell lines was previously reported (10). HCC cells, including HepG2, Huh7 and HLE, were first treated with VK2 at 
A

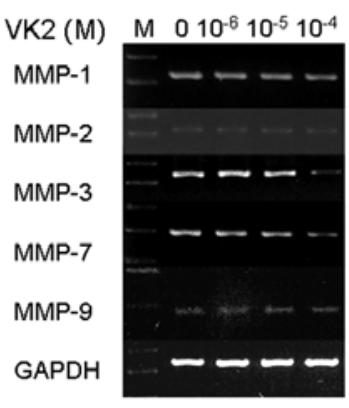

HepG2

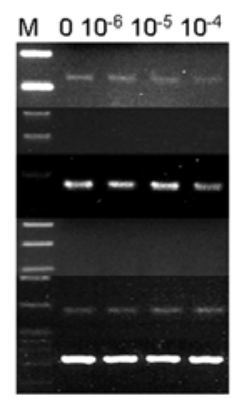

Huh7

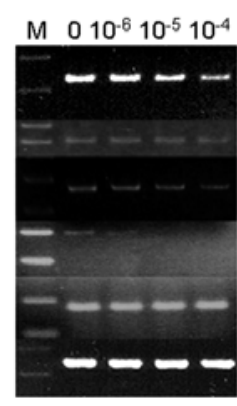

HLE

\section{B}

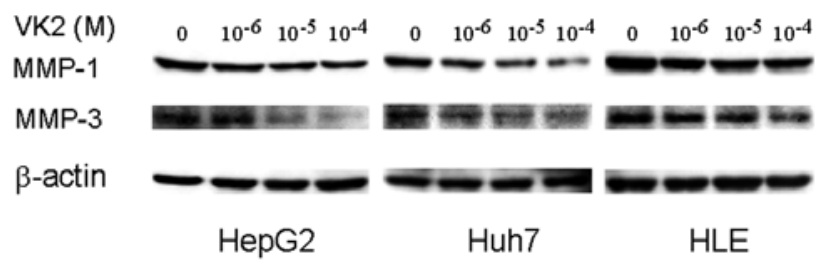

C

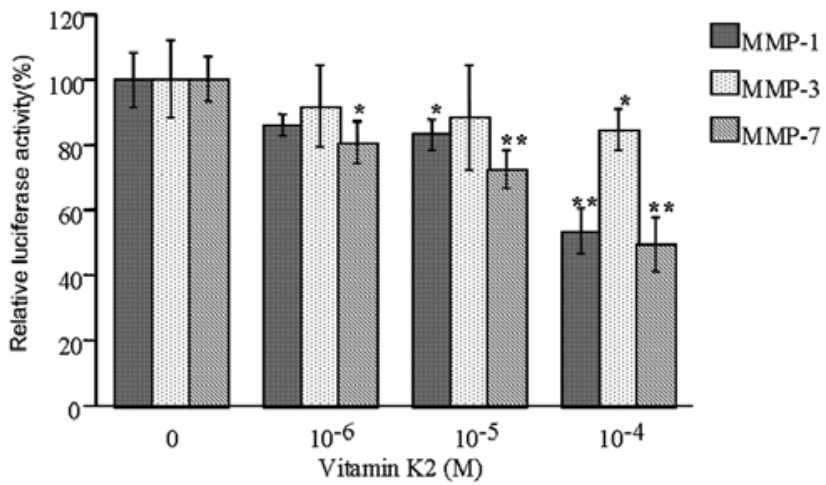

Figure 1. The effects of VK2 on MMP expression in human HCC cells. (A) Representative results of semi-quantitative RT-PCR for MMP-1, -2, -3, -7 and -9 mRNA in HepG2, Huh7 and HLE cells. Glyceraldehyde 3-phosphate dehydrogenase (GAPDH) expression was used as a control. The cells were treated with VK2 for $48 \mathrm{~h}$ at the indicated concentrations and total RNA was subjected to RT-PCR. M, DNA size marker. (B) A Western blot analysis of MMP-1 and -3 protein expression in VK2-treated HCC cells for $48 \mathrm{~h}$. The expression of $\beta$-actin was used as a control. (C) Effects of VK2 on MMP-1, -3 , and -7 promoter activity in HCC cells. The cells were transiently transfected with MMP-1, -3 and $-7 /$ luciferase plasmids, then treated with VK2 at the indicated concentrations for $48 \mathrm{~h}$. The columns indicate the mean obtained from three independent experiments; the bars indicate the standard deviation (SD); ${ }^{*} \mathrm{P}<0.05 ;{ }^{* *} \mathrm{P}<0.01$ in comparison to the cells untreated with VK2.

concentration of $0,10^{-6}, 10^{-5}$ and $10^{-4} \mathrm{M}$ for $48 \mathrm{~h}$. The expression of MMP-1, $-2,-3,-7$ and -9 mRNA was examined by semi-quantitative RT-PCR. In the HepG2 cells, VK2 dose-dependently suppressed MMP-1, -3 and -7 mRNA expression while MMP-2 and -9 expression were not affected (Fig. 1A, left). In the Huh7 cells, VK2 reduced the expression of MMP-1 and -3 mRNA dose-dependently, MMP-2 and -9 mRNA were unchanged and MMP-7 mRNA remained undetectable (Fig. 1A, center). In the HLE cells a relatively high expression of MMP-1, $-2,-7$ and -9 mRNA were detected,

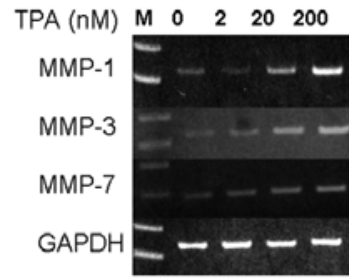

HepG2

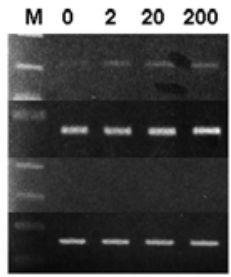

Huh7

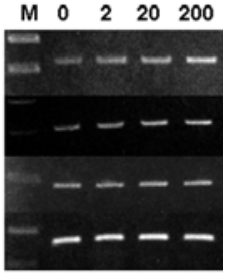

HLE
Figure 2. The induction of MMP mRNAs by 12-O-tetradecanoyl phorbol13-acetate (TPA). HepG2, Huh7 and HLE cells were treated with TPA for $24 \mathrm{~h}$ at the indicated concentrations. Semi-quantitative RT-PCR for MMP-1, -3 and -7 was performed. GAPDH was detected as a control. M, DNA size marker.

but the expression of MMP-3 mRNA was faint. After VK2 treatment, the MMP-1 and -3 mRNA expression was decreased and MMP-7 became undetectable, but the MMP-2 and -9 mRNA expression was not altered (Fig. 1A, right). The expression of MMP proteins was detected by either Western blotting or zymography. MMP-1 and -3 proteins were detected in the HepG2, Huh7 and HLE cells, but MMP-7 protein was undetectable. VK2 treatment dose-dependently suppressed the MMP-1 and -3 proteins in HepG2, Huh7 and HLE cells while B-actin remained unchanged (Fig. 1B). MMP-2 and -9 activities in the supernatant of these cells were detected by zymography. VK2 treatment did not change the $92 \mathrm{~K}$ and $72 \mathrm{~K}$ gelatinase activity in these cells (data not shown).

To investigate the mechanism of suppression of MMP-1, -3 and -7 expression by VK2, HCC cells were transiently transfected with MMP-1, -3 and -7 promoter/luciferase reporter plasmids and then were treated with VK2 for $48 \mathrm{~h}$. As shown in Fig. 1C, VK2 dose-dependently reduced MMP-1 and -7 promoter activity by $\sim 50 \%$ at $10^{-4} \mathrm{M}$ and decreased MMP-3 promoter activity weakly in the HepG2 cells. Similar results were obtained from the Huh7 and HLE cells (data not shown).

VK2 inhibits TPA-induced MMPs expression in HCC cells. TPA, a PKC activator, is known to induce multiple MMPs expression in many types of cells $(22,23)$. As shown in Fig. 2, TPA dose-dependently increased MMP-1, -3 and -7 mRNA in HCC cells. Among the HCC cells investigated, HepG2 expressed all MMP-1, -3 and -7 mRNAs and it was also responsive to both VK2 and TPA and the following experiments were performed by HepG2 cells.

Since VK2 inhibited MMP-1, -3 and -7 mRNA expression, the ability of VK2 to suppress TPA-induced MMP expression was investigated. As shown in Fig. 3A, VK2 dose-dependently inhibited MMP-1, -3 and -7 mRNA expression induced by TPA. VK2 also suppressed the MMP-1 and -3 protein expression induced by TPA (Fig. 3B). MMP-7 protein could not be detected by Western blotting in HepG2 cells.

Furthermore, as shown in Fig. 3C, VK2 dose-dependently suppressed the MMP-1, -3 and -7 promoter activity induced by TPA, thus suggesting that VK2 might inhibit the MMP expression through a PKC-mediated pathway.

TPA activates the AP-1 and $N F-\kappa B$ transcriptional activity and $V K 2$ suppresses TPA-induced $A P-1$ and $N F-\kappa B$ activity. Since 
A
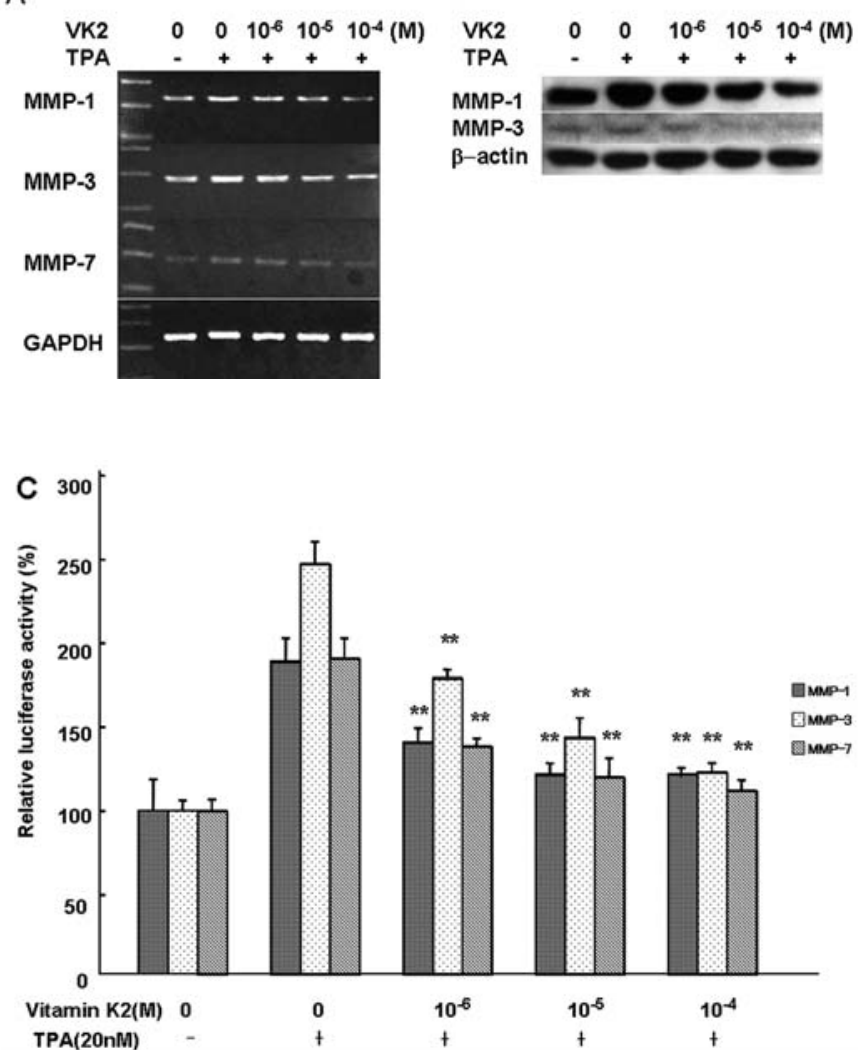

Figure 3. VK2 inhibited TPA-induced MMP-1, -3 and -7 mRNA (A), protein (B) and promoter activity (C). HepG2 cells were treated, with or without VK2, at the indicated concentrations and $20 \mathrm{nM}$ of TPA. (A) MMP-1, -3, -7 and GAPDH mRNA were detected by semi-quantitative RT-PCR. (B) MMP-1, $-3,-7$ and $B$-actin were evaluated by Western blotting. (C) The changes in the MMP-1, -3 and -7 promoter activity were examined by a luciferase assay. The data are expressed as the mean \pm SD from three independent experiments. ${ }^{*} \mathrm{P}<0.05 ;{ }^{* *} \mathrm{P}<0.01$ in comparison to the cells untreated with VK2.

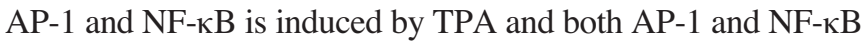
are known to be involved in the regulation of MMP expression (3), the next experiments investigated the effects of VK2 on TPA-induced AP-1 and NF-кB activity in HCC cells. HepG2 cells were treated with $20 \mathrm{nM}$ of TPA and various concentrations of VK2. VK2 dose-dependently inhibits the NF-кB activation stimulated by cytokines and TPA via inhibition of IKK activity (24). In line with the findings of previous studies, VK2 suppressed the TPA-induced NF- $\mathrm{B}$ transcriptional activation, and a known NF- $\mathrm{KB}$ inhibitor, parthenolide (25), suppressed the TPA-induced NF- $\mathrm{KB}$ activation (Fig. 4A).

As shown in Fig. 4B, VK2 inhibited TPA-induced AP-1 activity. The activation of AP-1 is known to be mediated by mitogen-activated protein (MAP) kinase cascades and the pathway involved in the VK2-mediated suppression of AP-1 induced by TPA was investigated. HepG2 cells were pretreated with pathway-specific inhibitors, PD98059 (ERK inhibitor), SB203580 (p38 inhibitor) and SP600125 (JNK inhibitor), then the cells were treated with $20 \mathrm{nM}$ of TPA. As shown in Fig. 4B, PD98059 and SP600125 readily suppressed the TPA-induced AP-1 activation while SB203580 did not affect the TPA-induced AP-1 activity, thus suggesting that VK2 inhibited the TPA-induced AP-1 transcriptional activity via the suppression of ERK and JNK phosphorylation.
A

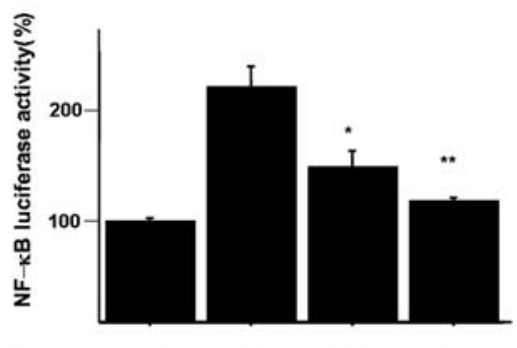

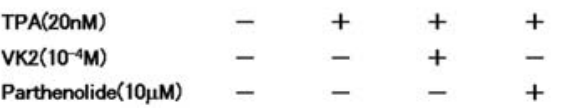

B
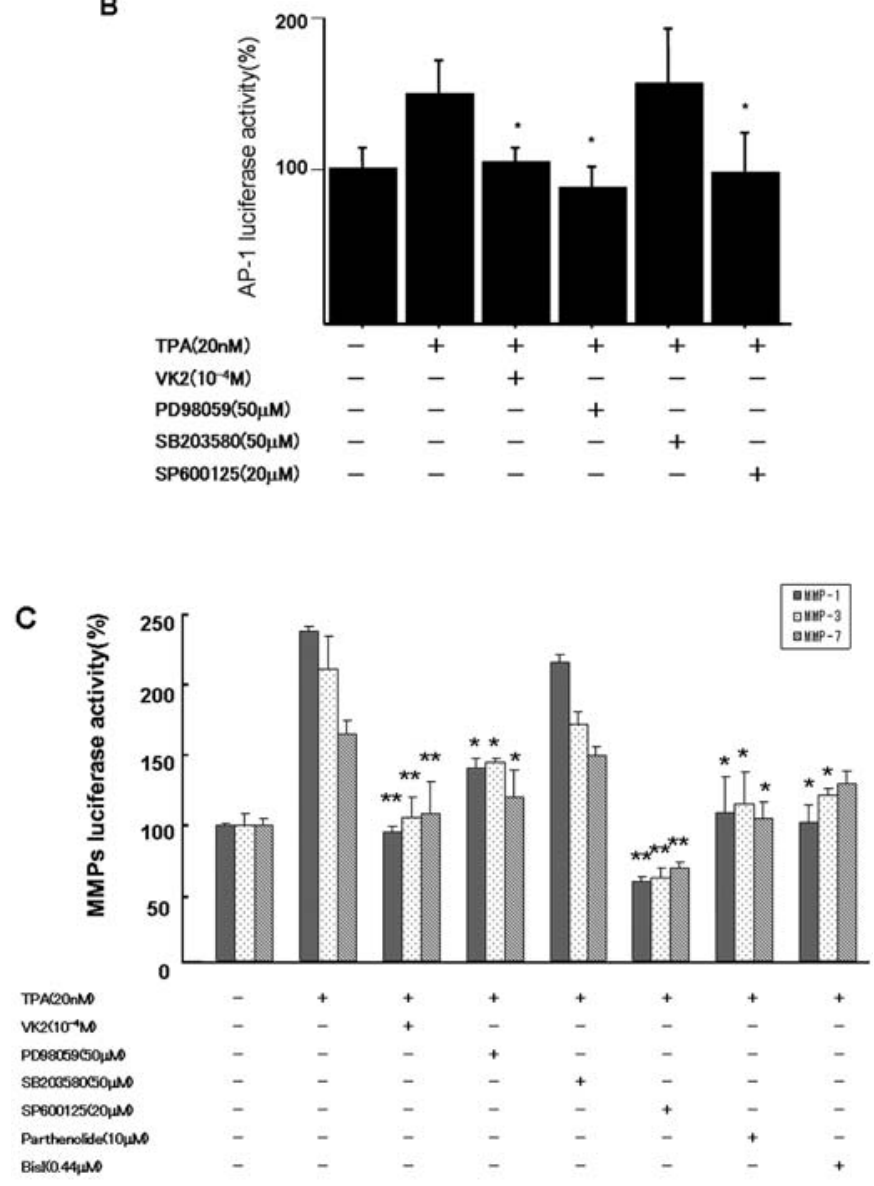

Figure 4. (A) The inhibitory effect of VK2 on NF- $\mathrm{KB}$ transcriptional activity. NF-кB-1-luciferase plasmids were transfected into HepG2 cells using a Dual-Reporter assay system (Promega). The treatment of cells with $20 \mathrm{nM}$ of TPA increased the NF- $\mathrm{KB}$ activity to 2.2 -fold and $10^{-4} \mathrm{M}$ of VK2 reduced the TPA-induced NF- $\kappa \mathrm{B}$ activity to $70 \%$. A NF- $\kappa \mathrm{B}$ inhibitor, prathenolide, mimicked the effect of VK2. (B) The inhibitory effects of VK2 on AP-1 transcriptional activity. HepG2 cells were transiently transfected with AP-1luciferase plasmids and subjected to luciferase assay. TPA $(20 \mathrm{nM})$ increased AP-1 activity to 1.1 -fold and $10^{-4} \mathrm{M}$ of VK2 reduced the TPA-induced AP-1 activity to 70\%. PD98059 (ERK inhibitor) and SP600125 (JNK inhibitor) inhibited the TPA-induced AP-1 activation, but SB203580 did not suppress TPA-induced AP-1 increase. (C) Inhibitory effects of VK2 and each signal transduction pathway-specific inhibitors on MMP-1, -3 and -7 promoter activity. HepG2 cells were transfected with MMP-1, -3 and -7 promoter/ luciferase plasmids using a Dual-Reporter assay system. The treatment of the cells with $20 \mathrm{nM}$ of TAP increased the MMPs promoter activity to 1.62.4-fold. The pretreatment of cells with VK2 and pathway-specific inhibitors including PD98059, SP600125, parthenolide and bisindolylmaleimide (non-specific PKC inhibitor) except SB203580, inhibited the TPAinduced MMPs promoter activation. The data are presented as the means $\pm \mathrm{SD}$ of three independent experiments and expressed as the percentage. ${ }^{*} \mathrm{P}<0.05$, ${ }^{* *} \mathrm{P}<0.01$ in comparison to the TPA alone group. 
TPA-induced MMP expression requires both the MAP kinase and $N F-\kappa B$ pathway. HepG2 cells transfected with MMP-1, -3 and -7 promoter/luciferase were pretreated with VK2, PD98059, SB203580, SP600125, parthenolide and bisindolylmaleimide (non-specific PKC inhibitor) at the indicated concentrations and then the cell were treated with $20 \mathrm{nM}$ of TPA. As shown in Fig. 4C, VK2 and the pathway-specific inhibitors, except for SB203580 (p38 inhibitor), inhibited the TPA-induced MMP-1, -3 and -7 promoter activation.

\section{Discussion}

Vitamin $\mathrm{K} 2$ is a cofactor of $\gamma$-carboxylation, which is necessary to produce functional blood coagulation factors. Vitamin K2 is also involved in the bone metabolism via the $\gamma$-carboxylation of bone matrix proteins and the regulation of bone reabsorption. Previous studies have revealed that VK2 are involved not only in $\gamma$-carboxylation of proteins but also in the $\gamma$-carboxylation independent function, thus suggesting that VK2 possess both $\gamma$-carboxylation-dependent and -independent actions (26). As an example of the $\gamma$-carboxylationindependent action of VK2, vitamin Ks has been demonstrated to have an anti-proliferative effect in many types of cancer cells including HCC $(14,15,18,20,24,26-30)$. In addition to anti-proliferative effects, VK2 also suppresses the invasion of HCC cells (18). While the mechanism by which VK2 exerts an anti-proliferative effect is largely attributed to the ability of VK2 to induce cell cycle arrest and/or apoptosis, the mechanisms of the invasion-suppressive effects of VK2 remain to be elucidated.

The current study demonstrated that VK2 inhibited basal and TPA-induced MMP-1, -3 and -7 expression in a dosedependent manner, although the expression levels of the MMPs and their response to TPA varied from cell to cell. MMPs play an important role in both the invasion and metastasis of tumor cells by degrading the ECM (3) and TPA, which is a tumor promoter, enhancing the expression of multiple MMPs (22). The expression of MMP is mainly controlled at the transcriptional level. The promoter regions of these MMPs show several common features and contain several responsive elements to common transcription factors such as AP-1, Ets, and/or NF-кB $(3,23)$. VK2 inhibits the growth of HCC cells by suppressing cyclin D1 expression through an inhibition of $\mathrm{NF}-\kappa \mathrm{B}$ activation (24). The NF- $\kappa \mathrm{B}$ activity is required for the induction of multiple MMPs, even when the promoter regions of some MMPs do not contain an apparent NF- $\mathrm{BB}$ binding site $(3,31,32)$. Therefore, the VK2-mediated inhibition of $\mathrm{NF}-\kappa \mathrm{B}$ is thought to be involved in the suppression of multiple MMPs

VK2 also suppresses the MAP kinase pathway and synergistically enhances retinoid-induced growth suppression of HCC cells by inducing apoptosis (33). TPA induces the activation of the MAP kinase pathway that involves the phosphorylation of specific threonine and tyrosine residues of the components of AP-1 transcription factor such as c-Fos and c-Jun, leading to the translocation to the nucleus and the activation of AP-1-dependent transcription (34). The current data showed that VK2 inhibited the TPA-induced transcriptional activity of AP-1 along with the suppression of MMP-1, -3 and -7 promoter activity. Since the transcription of these MMPs is dependent on AP-1, it is likely that the reduction of AP-1-dependent transcription by VK2 treatment contributes to the suppression of MMPs promoter activity. Generally there are three classes of the MAPK pathway: ERK, p38 and JNK. The MAPK pathway involved in TPA-induced AP-1 activation was also investigated. HCC cells were pretreated with specific inhibitors against ERK, p38 and JNK. The inhibitors against ERK and JNK, but not p38, abrogated the TPA-induced AP-1 transcriptional activity as well as VK2, thus suggesting that VK2 suppresses TPA-induced MMPs expression through a reduced AP-1 activity via the inhibition of the ERK and JNK pathways.

$\mathrm{PKC}$ is a serine/threonine kinase, activated by phorbol ester and it is thought to be the major phorbol ester receptor in the cell. Once activated, PKC plays a key regulatory role in a variety of cellular functions, such as the stimulation or repression of growth, changes in morphology and modulation of gene expression (35). PKC is a family of related proteins, and specific isoforms play pivotal roles in several transduction pathways including NF- $\mathrm{KB}$ and the MAP kinase pathway. TPA stimulates multiple MMP genes and an individual PKC isoform has been shown to regulate MMPs promoter activity in an isoform-specific manner $(3,22,23)$. The current study showed that VK2 inhibited TPA-mediated activation of AP-1 and $\mathrm{NF}-\kappa \mathrm{B}$, thus suggesting that VK2 might act as a PKC inhibitor and exert its inhibitory effects on MMP expression through MAPK-AP-1 and/or the NF-кB pathway. At this point it is not known which PKC isoform is responsible for VK2induced suppression of MMPs and further studies are thus required to clarify the VK2 action on the individual PKC isoforms.

Recently, many anti-cancer reagents have been developed. One of the major targets for a chemotherapeutic agent is the protein kinases, which play a critical role in both the development and progression of cancers. PKCs are regarded as one of the major targets of anti-cancer drug development as well as the other serine/threonine kinases and tyrosine kinases $(36,37)$. Several kinase inhibitors are now under clinical trials and some of them have already shown promising results as anti-cancer reagents (38). VK2 has been previously shown to affect the tyrosine-phosphorylation status of cells (39) and recent studies also demonstrated that VK2 down-regulated ERK and IKK activity $(24,26)$, both of which play important roles in the development and progression of cancers, thus suggesting the multikinase inhibitory action of VK2. Therefore, VK2 is a potential anti-cancer reagent that suppresses the growth and invasion of cancer cells as a multikinase inhibitor.

\section{Acknowledgements}

This study was supported, in part, by grants-in-aid for scientific research from the Ministry of Education, Culture, Sports, Science and Technology of Japan to I.O. (P-03346) and to T.M. (No. 16590606).

\section{References}

1. Llovet JM, Bourroghs A and Bruix J: Hepatocellular carcinoma. Lancet 362: 1907-1917, 2003.

2. Okuda K: Hepatocellular carcinoma. J Hepatol 32: 225-237, 2000. 
3. Westermarck $\mathbf{J}$ and Kahari VM: Regulation of matrix metalloproteinase expression in tumor invasion. FASEB J 13: 781-792, 1999.

4. Okazaki I, Wada N, Nakano M, Saito A, Takasaki K, Doi M, Kameyama K, Otani Y, Kubochi K, Niioka M, Watanabe T and Maruyama K: Differences in gene expression for matrix metalloproteinase-1 between early and advanced hepatocellular carcinoma. Hepatology 25: 580-584, 1997.

5. Yamamoto H, Itoh F, Adachi Y, Sakamoto H, Adachi M, Hinoda $\mathrm{Y}$ and Imai $\mathrm{K}$ : Relation of enhanced secretion of active matrix metalloproteinases with tumor spread in human hepatocellular carcinoma. Gastroenterology 112: 1290-1296, 1997.

6. Arii S, Mise M, Harada T, Furutani M, Ishigami S, Niwano M, Mizumoto M, Fukumoto M and Imamura M: Overexpression of matrix metalloproteinase 9 gene in heopatocellular carcinoma with invasive potential. Hepatology 24: 316-322, 1996.

7. Ashida K, Nakatsukasa H, Higashi T, Ohguchi S, Hino N, Nouso K, Urabe Y, Yoshida K, Kinugasa N and Tsujii T: Cellular distribution of 92-kD type IV collagenase/gelatinase B in human hepatocellular carcinoma. Am J Pathol 149: 1803-1811, 1996.

8. Harada T, Arii S, Mise M, Imamura T, Higashitsuji H Furutani M, Niwano M, Ishigami S, Fukumoto M, Seiki M, Sato $\mathrm{H}$ and Imamura $\mathrm{M}$ : Membrane-type matrix metalloproteinase-1 (MT1-MMP) gene is overexpressed in highly invasive hepatocellular carcinomas. J Hepatol 28: 231-239, 1998.

9. Ozaki I, Mizuta T, Zhao G, Yotsumoto H, Hara T, Kajihara S, Hisatomi A, Sakai T and Yamamoto K: Involvement of the Ets-1 gene in overexpression matrilysin in human hepatocellular carcinoma. Cancer Res 60: 6519-6525, 2000.

10. Ozaki I, Mizuta T, Zhao G, Zhang H, Yoshimura T, Kawazoe S, Eguchi Y, Yasutake T, Hisatomi A, Sakai T and Yamamoto K: Induction of matrix metalloproteinase genes in human hepatocellular carcinoma by hepatocyte growth factor via a transcription factor Ets-1. Hepatol Res 27: 288-300, 2003

11. Furie B, Bouchard BA and Furie BC: Vitamin K-dependent biosynthesis of $\gamma$-carboxylglutamic acid. Blood 93: 1798-1808, 1999.

12. Shearer $\mathrm{MJ}$ : The roles of vitamin $\mathrm{D}$ and vitamin $\mathrm{K}$ in bone health and osteoporosis prevention. Proc Nutr Soc 56: 915-937, 1997.

13. Sakai I, Hashimoto S, Yoda M, Hida T, Ohsawa S, Nakajo S, and Nakaya K: Novel role of vitamin K2: a potent inducer of differentiation of various human myeloid leukemia cell lines. Biochem Biophys Res Commun 205: 1305-1310, 1994.

14. Wu FYH, Liao WC and Chang HM: Comparison of antitumor activity of vitamins $\mathrm{K} 1, \mathrm{~K} 2$, K3 on human tumor cells by two (MTT and SRB) assays. Life Sci 52: 1797-1804, 1993

15. Nishikawa Y, Carr BI, Wang M, Kars S, Finn F, Dowd P, Zheng ZB, Kerns J and Naganathan S: Growth inhibition of hepatoma cells induced by vitamin $\mathrm{K}$ and its analog. J Biol Chem 270: 28304-28310, 1995.

16. Mizuta T, Ozaki I, Eguchi Y, Yasutake T, Kawazoe S, Fujimoto K and Yamamoto K: The effect of menatetrenone, a vitamin K2 analog, on recurrence and survival in patients with hepatocellular carcinoma after curative treatment: a pilot study. Cancer 106: 867-872, 2006.

17. Habu D, Shiomi S, Tamori A, Takeda T, Tanaka T, Kubo S and Nishiguchi S: Role of vitamin K2 in the development of hepatocellular carcinoma in women with viral cirrhosis of the liver. JAMA 292: 358-367, 2004.

18. Otsuka M, Kato N, Shao RX, Hoshida Y, Ijichi H, Koike Y, Taniguchi H, Moriyama M, Shiratori Y, Kawabe T and Omata M: Vitamin K2 inhibits the growth and invasiveness of hepatocellular carcinoma cells via protein kinase A activation. Hepatology 40: 243-251, 2004

19. Yoshiji H, Kuriyama S, Noguchi R, Yoshii J, Ikenaka Y, Yanase K, Namisaki T, Kitade M, Yamazaki M, Masaki T and Fukui H: Combination of vitamin $\mathrm{K} 2$ and the angiotensinconverting enzyme inhibitor, perindopril, attenuates the liver enzyme-altered preneoplastic lesions in rats via angiogenesis suppression. J Hepatol 42: 687-693, 2005.

20. Sakakima Y, Hayakawa A, Nagasaka T and Nakao A: Prevention of hepatocarcinogenesis with phosphatidylcholine and menaquinone-4: in vitro and in vivo experiments. J Hepatol 47: 83-92, 2007.
21. Leber TM and Balkwill FR: Zymography: a single-step staining method for quantitation of proteolytic activity on substrate gels. Anal Biochem 249: 24-28, 1997.

22. Mckay AR, Ballin M, Pelina MD, Farina AR, Nason AM, Hartzler JL and Thorgeirsson UP: Effect of phorbol ester and cytokines on matrix metalloproteinases and tissue inhibitor of metalloproteinase expression in tumor and normal cell lines. Invasion Metastasis 18: 168-184, 1992.

23. Reifel-Miller AE, Conarty DM, Valasek KM, Iversen PW, Burns DJ and Birch KA: Protein kinase $\mathrm{C}$ isozymes differentially regulate promoters containing PEA3/12-O-tetradecanoyl-13actate response element motifs. J Biol Chem 271: 21666-21671, 1996.

24. Ozaki I, Zhang H, Mizuta T, Ide Y, Eguchi Y, Yasutake T, Sakamaki T, Pestell RG and Yamamoto K: Menatetrenone, a vitamin $\mathrm{K} 2$ analogue, inhibits hepatocellular carcinoma cell growth by suppressing cyclin D1 expression through inhibition of nuclear factor $\kappa \mathrm{B}$ activation. Clin Cancer Res 13: 2236-2245, 2007.

25. Hehner SP, Hofmann TG, Droge W and Schmitz ML: The anti-inflammatory sequiterpene lactone parthenoide inhibits NFkappa B by tarteting the I kappa B kinase complex. J Immunol 163: 5617-5623, 1999.

26. Carr BI, Wang Z and Kar S: K vitamins, PTP antagonism, and cell growth arrest. J Cell Physiol 193: 263-274, 2002.

27. Tokita H, Tsuchida A, Miyazawa K, Ohyashiki K, Katayanagi S, Sudo H, Enomoto M, Takagi Y and Aoki T: Vitamin K2-induced antitumor effects via cell-cycle arrest and apoptosis in gastric cancer cell line. Int J Mol Med 17: 235-243, 2006.

28. Tsukioka T, Miura Y, Otsuki T, Nishimura Y, Hyodoh F, Wada H and Sugihara T: The mechanisms of vitamin K2-induced apoptosis of myeloma cells. Haematologica 91: 613-619, 2006.

29. Yokoyama T, Miyazawa K, Yoshida T and Ohyashiki K: Combination of vitamin $\mathrm{K} 2$ plus imatinib mesylate enhances induction of apoptosis in small cell lung cancer cell lines. Int J Oncol 26: 33-40, 2005.

30. Sibayama-Imazu T, Sonoda I, Sakairi S, Aiuchi T, Ann W, Nakajo S, Itabe $\mathrm{H}$ and Nakaya K: Production of superoxide and dissipation of mitochondrial transmembrane potential by vitamin $\mathrm{K} 2$ trigger apoptosis in human ovarian cancer TYK-nu cells. Apoptosis 11: 1535-1543, 2006

31. Bond M, Baker AH and Newby AC: Nuclear factor $\kappa \mathrm{B}$ activity is essential for matrix metalloproteinase-1 and -3 upregulation in rabbit dermal fibroblast. Biochem Biophys Res Commun 264: 561-567, 1999.

32. Wroblewski LE, Noble PJM, Pagliocca A, Pritchard DM, Hart A, Campbell F, Dodson AR, Dockray GJ and Varro A: Stimulation of MMP-7(matrilysin) by Helicobacter pylori in human gastric epithelial cells: role in epithelial cell migration. J Cell Sci 116: 3017-3026, 2003.

33. Kanamori T, Shimizu M, Okuno M, Matsushima-Nishiwaki R, Tsurumi H, Kojima S and Moriwaki H: Synergistic growth inhibition by acyclic retinoid and vitamin $\mathrm{K} 2$ in human hepatocellular carcinoma cells. Cancer Sci 98: 431-437, 2007.

34. Karin M: The regulation of AP-1 activity by mitogen-activated protein kinases. J Biol Chem 270: 16483-16486, 1995.

35. Newton AC: Protein kinase C; structure, function and regulation. J Biol Chem 270: 28495-28498, 1995.

36. Mackay HJ and Tweleves CJ: Protein kinase C: a target for anticancer drugs? Endocrine-Related Cancer 10: 389-396, 2003.

37. Ventura JJ and Nebreda AR: Protein kinases and phosphatases as therapeutic targets in cancer. Clin Trans Oncol 8: 153-160, 2006.

38. Wilhelm S, Carter C, Lynch M, Lowinger T, Dumas J, Smith RA, Schwartz B, Simantov R and Kelley S: Discovery and development of sorafenib: a multikinase inhibitor for treating cancer. Nat Rev Drug Discov 5: 835-844, 2006.

39. Saxena SP, Fan T, Li M and Israels ED: A novel role for vitamin $\mathrm{K} 1$ in a tyrosine phosphorylation cascade during chick embryogenesis. J Clin Invest 99: 602-607, 1997. 